\section{Need for decriminalisation of suicide in low- and middle-income countries}

Sir: The guest editorial in the February issue by Pathare et al (2014) about the need to reform mental health legislation in Commonwealth nations highlighted the fact that many countries have laws that are out of date. The criminalisation of suicide is an important example that warrants urgent attention and reform.

In 13th-century England, 'self-murder' was considered a mortal sin. Those who died by suicide were denied a Christian burial and their property was confiscated from their families. Even as recently as 1956, people surviving a suicide attempt were subject to criminal proceedings, with penalties ranging from probation and fines to prison sentences, rather than a psychiatric assessment and treatment. After some urging from both the medical profession and even the churches by that time, in 1961 the British Parliament finally enacted the Suicide Act, whereby attempted suicide ceased to be an offence (Holt, 2011). In contrast, many continental European countries had done so much earlier, beginning with the French Revolution of 1789 (Law Commission of India, 2008).

Unfortunately, as a legacy of British colonialism, the criminalisation of suicide continues in a majority of Commonwealth countries, including India, Bangladesh, Pakistan, Singapore, Malaysia, Ghana and Uganda (Law Commission of India, 2008; Adinkrah, 2012; The Hindu, 2013), despite the World Health Organization consistently objecting that labelling suicidal behaviours as a punishable offence has a negative effect on public health (Law Commission of India, 2008). The criminalisation of suicide is known to deter those who are considering suicide from seeking emotional, physical and mental health support. It also skews data collection regarding suicide statistics, as suicide attempts tend to be registered instead as accidental poisonings, for example. The consequent lack of reliable data means that the extent of the problem is unknown, which in turn makes effective intervention strategies more difficult to formulate (Law Commission of India, 2008).

The Law Commission of India (2008) reiterated the conclusion of a 1971 report in highlighting the need to decriminalise suicide. It further stated that suicide attempts "may be regarded more as a manifestation of a diseased condition of mind deserving treatment and care rather than an offence to be visited with punishment'. It cited the example of Sri Lanka (perhaps an exception among Commonwealth countries), where suicide was decriminalised in early 2000 and where the suicide rate is tending to decrease.

Since 1970, many social activists and mental health professionals in India have been clamouring for the decriminalisation of suicide (Law Commission of India, 2008). Thankfully, in August 2013 a bill to amend the India's mental health law was proposed. The bill seeks to decriminalise acts of suicide by explicitly clarifying that the act of suicide and the mental health of the person are inseparably linked, and have to be seen together rather than in isolation. It is important to note that the bill also seeks to provide for mental healthcare for persons with mental illnesses and to protect, promote and fulfil the rights of such persons during the delivery of mental healthcare and services. We sincerely hope that the bill becomes an Act of Parliament as soon as possible.

More widely, it is imperative that everyone recommends and supports the decriminalisation of suicide as an element of progressive mental health treatment and suicide prevention strategies throughout the Commonwealth as well as in other low- and middle-income countries.

\section{A. Mukherjee ${ }^{1}$ and R. Bhandarkar ${ }^{2}$}

${ }^{1}$ ST4 LAS in Psychiatry, Old Oak Mental Health Recovery Team, West London Mental Health Trust, UK, email Amit.Mukherjee@ nhs.net; ${ }^{2}$ Consultant Psychiatrist, National Brain Injury Centre, St Andrews Healthcare, Northampton, UK

Adinkrah, M. (2012) Criminal prosecution of suicide attempt survivors in Ghana. International Journal of Offender Therapy and Comparative Criminology, 57, 1477-1497.

Holt, G. (2011) When suicide was illegal. BBC news magazine website, 3 August. Available at http://www.bbc.co.uk/news/ magazine-14374296 (accessed 24 February 2014).

Law Commission of India (2008) Humanization and Decriminalization of Attempt to Suicide. Report No. 210. Available at http://lawcommissionofindia.nic.in/reports/report210.pdf (accessed 24 February 2014)

Pathare, S., Shields, L., Sagade, J., et al (2014) The need to reform mental health legislation in Commonwealth countries. International Psychiatry, 11, 1-2

The Hindu (2013) New mental health bill decriminalises suicide. The Hindu, 21 August. Available at http://www.thehindu.com/ news/national/new-mental-health-bill-decriminalises-suicide/ article5045156.ece (accessed 24 February 2014). 